\title{
Margarite pseudomorphs after corundum, Qôrqut area, Godthåbsfjord, West Greenland
}

\author{
Robert F. Dymek
}

\begin{abstract}
Margarite (end member $\mathrm{CaAl}_{2} \mathrm{Si}_{2} \mathrm{Al}_{2} \mathrm{O}_{10}$ ) is reported as nodular aggregates of fine-grained material partly replacing corundum and as fine dispersed material replacing biotite in an inclusion of migmatitic plagioclase-rich gneiss within the Qôrqut granite. Muscovite replaces biotite in the same sample. A retrograde reaction in the presence of volatiles is suggested in which biotite + plagioclase + corundum go to an assemblage containing margarite + muscovite + epidote.

Cell parameters and chemical data are presented. A maximum temperature for the reaction of $\sim 580^{\circ}$ at $5 \mathrm{~Kb}$ is suggested.
\end{abstract}

\section{Introduction}

During field work in Godthåbsfjord in 1975, centimeter-sized micaceous gray nodules were noted in migmatitic plagioclase-rich gneiss inclusions in the Qôrqut Granite Complex near Qupik (lat. $64^{\circ} 13^{\prime} \mathrm{N}$; long. $51^{\circ} 05^{\prime} \mathrm{W}$ ). Subsequent laboratory study showed these 'nodules' to be ruby corundum pseudomorphed by margarite. Although the occurrence of corundum was unexpected, this mineral is widespread-albeit uncommon-in the gneiss complex of West Greenland. However, the identification of margarite is of particular interest because it represents only the second recorded occurrence of the relatively rare mineral in all of Greenland.* Petrographic, chemical and X-ray data for the margarite and its associated minerals are presented below.

\section{Sample description}

The sample that was studied (GGU 209465) is a coarse-grained biotite-plagioclase-corundum gneiss. Corundum crystals range up to $\sim 1 \mathrm{~cm}$ across, and are deep-red in hand specimen, whereas in thin section they are reddish-brown and highly twinned. Biotite forms tabular grains up to $\sim 5 \mathrm{~mm}$ long that are pleochroic from pale-brown to green-brown. Plagioclase $\left(\sim \mathrm{An}_{60-80}\right)$ forms polygonal grains up to $\sim 1 \mathrm{~cm}$ across.

Corundum is partly to entirely replaced by margarite, which is silvery-gray in hand speci-

* Beech \& Chadwick (1980) noted a margarite-corundum association in the north-west Buksefjorden area, but did not present mineralogical data for that occurrence. 
Table 1. Microprobe analyses of micas in sample GGU 209465

\begin{tabular}{|c|c|c|c|c|c|c|c|}
\hline \multirow[b]{2}{*}{$\mathrm{SiO}_{2}$} & \multicolumn{2}{|c|}{ BIOTITE } & \multicolumn{2}{|c|}{ MUSCOVITE } & \multicolumn{3}{|c|}{ MARGARITE } \\
\hline & 33.64 & 34.84 & 45.08 & 45.73 & 30.76 & 30.25 & 30.22 \\
\hline $\mathrm{A}_{2} \mathrm{O}_{3}$ & 20.02 & 18.67 & 35.64 & 33.55 & 50.99 & 50.86 & 50.52 \\
\hline $\mathrm{Cr}_{2} \mathrm{O}_{3}$ & 0.08 & 0.01 & 0.06 & 0.00 & 0.01 & 0.04 & 0.05 \\
\hline $\mathrm{THO}_{2}$ & 1.22 & 1.20 & 0.18 & 0.21 & 0.07 & 0.05 & 0.02 \\
\hline $\mathrm{MgO}^{2}$ & 9.96 & 10.04 & 0.54 & 1.11 & 0.29 & 0.21 & 0.09 \\
\hline $\mathrm{FeO}^{*}$ & 19.69 & 19.28 & 2.61 & 3.45 & 0.66 & 0.46 & 0.36 \\
\hline Zno & 0.10 & 0.05 & 0.00 & 0.00 & 0.03 & 0.00 & 0.00 \\
\hline Mno & 0.22 & 0.25 & 0.00 & 0.00 & 0.03 & 0.01 & 0.00 \\
\hline $\mathrm{CaO}$ & 0.23 & 0.25 & 0.24 & 0.19 & 11.26 & 11.86 & 12.38 \\
\hline $\mathrm{BaO}$ & 0.16 & 0.02 & 0.16 & 0.04 & 0.02 & 0.03 & 0.01 \\
\hline $\mathrm{Na}_{2} \mathrm{O}$ & 0.14 & 0.11 & 0.54 & 0.30 & 1.62 & 1.34 & 0.79 \\
\hline $\mathrm{K}_{2} \mathrm{O}$ & 9.53 & 9.51 & 10.54 & 10.45 & 0.14 & 0.05 & 0.20 \\
\hline $\mathbf{F}$ & 0.20 & 0.25 & 0.01 & 0.00 & 0.00 & 0.00 & 0.00 \\
\hline $\mathrm{Cl}$ & 0.14 & 0.14 & 0.00 & 0.00 & 0.01 & 0.02 & 0.00 \\
\hline Total $^{+}$ & 95.21 & 94.48 & 95.60 & 95.03 & 95.87 & 95.18 & 94.64 \\
\hline \multicolumn{8}{|c|}{ FORMULA PROPORTIONS BASED ON 11 OXYGENS } \\
\hline Si & 2.593 & 2.693 & 3.022 & 3.089 & 2.031 & 2.013 & 2.021 \\
\hline A1 & 1.407 & 1.307 & 0.978 & 0.911 & 1.968 & 1.987 & 1.979 \\
\hline A] & 0.412 & 0.394 & 1.839 & 1.762 & 2.002 & 2.002 & 2.005 \\
\hline $\mathrm{Cr}$ & 0.005 & 0.001 & 0.003 & 0.000 & 0.001 & 0.002 & 0.003 \\
\hline Ti & 0.071 & 0.070 & 0.009 & 0.011 & 0.003 & 0.003 & 0.001 \\
\hline Mg & 1.145 & 1.157 & 0.054 & 0.112 & 0.029 & 0.021 & 0.009 \\
\hline $\mathbf{F e}$ & 1.269 & 1.247 & 0.146 & 0.195 & 0.036 & 0.026 & 0.020 \\
\hline $\mathrm{Zn}$ & 0.006 & 0.003 & 0.000 & 0.000 & 0.001 & 0.000 & 0.000 \\
\hline Mn & 0.014 & 0.016 & 0.000 & 0.000 & 0.001 & 0.001 & 0.000 \\
\hline Ca & 0.019 & 0.021 & 0.017 & 0.014 & 0.797 & 0.846 & 0.887 \\
\hline Ba & 0.005 & 0.001 & 0.004 & 0.001 & 0.001 & 0.001 & 0.000 \\
\hline $\mathrm{Na}$ & 0.021 & 0.016 & 0.070 & 0.039 & 0.207 & 0.173 & 0.102 \\
\hline$k$ & 0.937 & 0.938 & 0.901 & 0.901 & 0.012 & 0.004 & 0.017 \\
\hline
\end{tabular}

men and colorless to pale-brown in thin section. In certain cases, the prior existence of corundum is indicated by rounded margarite mats up to $\sim 1 \mathrm{~cm}$ in diameter. Two textural types of margarite are present: dense aggregates of fine-grained 50-100 $\mu \mathrm{m}$ flakes that replace corundum, and pale-brown plates up to $\sim 250 \mu \mathrm{m}$ long dispersed throughout the sample. Muscovite occurs as colorless tabular grains $(\sim 50-100 \mu \mathrm{m})$ that replace biotite, whereas epidote $[\mathrm{Al} /(\mathrm{Al}+\mathrm{Fe})=0.76-0.82]$ forms randomly oriented, acicular grains $(\sim$ $25 \times 250 \mu \mathrm{m})$ intergrown with biotite and muscovite.

It is unclear whether the protolith of this corundum-bearing gneiss was a desilicated anorthosite or some type of aluminous supracrustal lithology. In either case, apparent reaction with the surrounding granite has altered a primary assemblage of bio + plag + co to a retrograde one containing margarite + muscovite + epidote. 
Table 2. Margarite cell parameters

\begin{tabular}{lrrr}
\hline & 1. & 2. & 3. \\
\hline a & $5.105 \pm 0.004 A$ & $5.126 \pm 0.002 \AA$ & $5.104 \mathrm{~A}$ \\
b & $8.803 \pm 0.006 \AA$ & $8.855 \pm 0.003 \AA$ & $8.838 \mathrm{~A}$ \\
C & $19.192 \pm 0.014 \AA$ & $19.168 \pm 0.005 \AA$ & $19.117 \mathrm{~A}$ \\
B & $94.84 \pm 0.09^{\circ}$ & $95.45 \pm 0.06^{\circ}$ & $95.52^{\circ}$ \\
V & $859.26 \pm 0.87 \mathrm{~A}^{3}$ & $866.09 \pm 0.30 \mathrm{~A}^{3}$ & $858.09 \mathrm{~A}^{3}$ \\
\hline & & & \\
1. This study (209465). & & \\
2. Guidotti \& Cheney (1976) - margarite pseudomorphs \\
after chiastolite; Na/Na + Ca) $=0.29$. \\
3. Velde (ig71) - synthetic margarite.
\end{tabular}

\section{Mineralogical data}

Chemical compositions of all the phases in sample 209465 were determined by electron probe microanalysis. Particular attention was paid to the three micas, and representative analyses that span the range of measured compositions are listed in Table 1. Cell parameters for the margarite were obtained from standard powder diffractometer data using the program LCLSQ of Burnham (1975); these data are reported in Table 2.

Margarite [theoretical end-member formula: $\mathrm{Ca}^{\mathrm{A}}\left(\mathrm{Al}_{2} \mathrm{D}\right)^{\mathrm{VI}}\left(\mathrm{Si}_{2} \mathrm{Al}_{2}\right)^{\mathrm{IV}} \mathrm{O}_{10}(\mathrm{OH})_{2}$ ] contains only small amounts of $\mathrm{MgO}, \mathrm{FeO}, \mathrm{TiO}_{2}$ and $\mathrm{K}_{2} \mathrm{O}$, but has a high $\mathrm{Na}_{2} \mathrm{O}$-content $(\sim 0.7-1.4$ wt $\%$ ), indicating up to $\sim 20 \%$ Paragonite component $\left[\mathrm{Na}^{\mathrm{A}}\left(\mathrm{Al}_{2} \square\right)^{\mathrm{VI}}\left(\mathrm{Si}_{3} \mathrm{Al}\right)^{\mathrm{IV}} \mathrm{O}_{10}(\mathrm{OH})_{2}\right]$. Individual crystals are zoned, with $\mathrm{Na} /(\mathrm{Na}+\mathrm{Ca})$ increasing away from grain contacts with corundum. The high Paragonite content of the margarite in 209465 is similar to that reported from other localities (see Guidotti et al., 1979, for a recent summary).

Muscovite [theoretical end-member formula: $\mathrm{K}^{\mathrm{A}}\left(\mathrm{Al}_{2} \square\right)^{\mathrm{VI}}\left(\mathrm{Si}_{3} \mathrm{Al}\right)^{\mathrm{IV}} \mathrm{O}_{10}(\mathrm{OH})_{2}$ ] has high $\mathrm{MgO}$ (up to $1.3 \mathrm{wt} \%$ ) and $\mathrm{FeO}^{*}$ (up to $3.6 \mathrm{wt} \%$ ) indicating up to $10 \%$ Celadonite component $\left[\mathrm{K}^{\mathrm{A}}(\mathrm{AlFm} \square)^{\mathrm{VI}}\left(\mathrm{Si}_{4}\right)^{\mathrm{IV}} \mathrm{O}_{10}(\mathrm{OH})_{2}\right]^{* *}$. A similar amount of trioctohedral substitution $\left(3 \mathrm{R}^{2+}=2 \mathrm{Al}^{3+} \square\right)^{\mathrm{VI}}$ is also permitted by these data. $\mathrm{Na}_{2} \mathrm{O}$ ranges from $0.2-0.6$ wt $\%$, indicating up to $10 \%$ Paragonite. Muscovite that occurs with margarite in other localities contains similar amounts of $\mathrm{Na}, \mathrm{Mg}$ and Ti, but lower Fe (cf. Höck, 1974; Guidotti et al., 1979).

Biotite has $\mathrm{Fe} \approx \mathrm{Mg}$, but departs significantly from the compositional range of the Phlogopite-Annite series: $\mathrm{K}^{\mathrm{A}}\left(\mathrm{Fm}_{3}\right)^{\mathrm{VI}}\left(\mathrm{Si}_{3} \mathrm{Al}\right)^{\mathrm{IV}} \mathrm{O}_{10}(\mathrm{OH})_{2}{ }^{* *}$. It contains moderate $\mathrm{TiO}_{2}(\sim 1.2 \mathrm{wt}$ $\%)$ and high $\mathrm{Al}_{2} \mathrm{O}_{3}(\sim 18-21$ wt \%) indicating 30-40\% Eastonite component: $\mathrm{K}^{\mathrm{A}}\left(\mathrm{Fm}_{2} \mathrm{Al}\right)^{\mathrm{VI}}\left(\mathrm{Si}_{2} \mathrm{Al}_{2}\right)^{\mathrm{IV}} \mathrm{O}(\mathrm{OH})_{2}$. This high Al-content is consistent with the prior coexistence of biotite with corundum.

In all three micas, the contents of $\mathrm{Cr}_{2} \mathrm{O}_{3}, \mathrm{MnO}, \mathrm{ZnO}, \mathrm{BaO}, \mathrm{F}$ and $\mathrm{Cl}$ are low but variable.

The unit cell parameters listed in Table 2 are not unlike those reported for synthetic margarite by Velde (1971), and for a natural Na-rich margarite by Guidotti \& Cheney

\footnotetext{
* Since iron is analyzed as FeO with the microprobe, these values must be revised downward slightly in proportion to the amount of $\mathrm{Fe}_{2} \mathrm{O}_{3}$ that is present, which is not known.

${ }^{* *} \mathrm{Fm}=\mathrm{Mg}+\mathrm{Fe}+\mathrm{Mn}+\mathrm{Zn}$.
} 
(1976). However, there are slight systematic differences that exceed analytical error in all cases. The margarite in 209465 was refined against a $2 \mathrm{M}_{1}$ polytype, but the smaller value for $B$ compared to the other examples suggest that a different or mixed polytype may occur. The sources of these small differences in unit cell dimensions can only be resolved by detailed single-crystal X-ray study.

\section{Discussion}

The principal occurrence of margarite is as pseudomorphs after either corundum or aluminosilicates in terrains affected by polymetamorphism (cf. Deer et al., 1962; Guidotti et al., 1979; Baltatzis \& Katangas, 1981). Therefore, the occurrence described in this report for the polymetamorphic gneisses of the Godthåb District appears typical for margarite.

The presence of two textural types of margarite in 209465, together with the overall complex replacement features, suggests that the formation of margarite may have occurred in two stages such as the following:

$$
\text { Corundum }+ \text { Plagioclase }+\mathrm{H}_{2} \mathrm{O} \rightarrow \text { Margarite, }
$$

Which accounts for the fine-grained margarite rims on corundum, and

$$
\text { Biotite }+ \text { Plagioclase }+\mathrm{H}_{2} \mathrm{O} \rightarrow \text { Margarite }+ \text { Epidote }+ \text { Muscovite, }
$$

which accounts for the secondary epidote and muscovite, and the margarite dispersed throughout the sample 'matrix'. In simplified form, the net result of (1) and (2) would be:

$$
\begin{aligned}
& 1 / 2\left[\mathrm{Al}_{2} \mathrm{O}_{3}\right]_{\mathrm{Cor}}+4 {\left[\mathrm{CaAl}_{2} \mathrm{Si}_{2} \mathrm{O}_{8}\right]_{\mathrm{Plag}}+\mathrm{K}\left[\left(\mathrm{Fe}_{2}^{2+}, \mathrm{Al}\right)\left(\mathrm{Si}_{2} \mathrm{Al}_{2}\right) \mathrm{O}_{10}(\mathrm{OH})_{2}\right]_{\text {Bio }} } \\
&+1 / 2 \mathrm{O}_{2}+5 / 2 \mathrm{H}_{2} \mathrm{O}=2\left[\mathrm{CaAl}_{2} \mathrm{Si}_{2} \mathrm{Al}_{2} \mathrm{O}_{10}(\mathrm{OH})_{2}\right]_{\mathrm{Marg}}+\left[\mathrm{Ca}_{2} \mathrm{AlFe}_{2}^{3+} \mathrm{Si}_{3} \mathrm{O}_{12}(\mathrm{OH})\right]_{\mathrm{Ep}} \\
&+\left[\mathrm{KAl}_{2} \mathrm{Si}_{3} \mathrm{AlO}_{10}(\mathrm{OH})_{2}\right]_{\text {Musc }}
\end{aligned}
$$

This reaction is highly schematic, but can be modified with the addition of $\mathrm{NaSi}=\mathrm{CaAl}$ and $\mathrm{Mg}=\mathrm{Fe}$ exchange substitutions to account for $\mathrm{Na}$ in plagioclase and micas, and $\mathrm{Mg}$ in the micas. Nevertheless, the important point here is that the simultaneous formation of margarite, muscovite and epidote does not seem to require the addition of any species except volatiles. For example, if silica were added, one would expect an aluminosilicate phase to develop (andalusite or kyanite), which has not occurred.

The conditions of formation for the margarite can be estimated from geological relationships and relevant experimental studies. If the margarite in 209465 formed by reaction with surrounding Qôrqut granite, as proposed here, then a reasonable maximum pressure would be $<\sim 5 \mathrm{~kb}$. The thermal stability of margarite in the system $\mathrm{CaO}-\mathrm{Al}_{2} \mathrm{O}_{3}-\mathrm{SiO}_{2}-\mathrm{H}_{2} \mathrm{O}$ has been investigated experimentally by Chatterjee (1970), Velde (1971) and Storre \& Nitsch (1974). For $\mathrm{P}_{\mathrm{H}_{2} \mathrm{O}}=5 \mathrm{~kb}$, the reaction margarite = corundum + anorthite $+\mathrm{H}_{2} \mathrm{O}$ has been bracketed at $\sim 580^{\circ} \mathrm{C}$. This would represent a maximum for 209465 because the high $\mathrm{Na}$-content of the margarite would lower the reaction temperature slightly.

Acknowledgements. The laboratory portion of this work was supported by the National Science Foundation (Grant EAR 78-23412). Field support in 1975 was provided by the Geological Survey of Green- 
land. The writer wishes to thank Theodore Johnson for carrying out the X-ray diffraction studies, and Carl Francis for the original identification of the margarite. Comments on the manuscript by the staff of the Geological Survey of Greenland have been most useful.

\section{References}

Baltatzis, E. \& Katangas, C. 1981: Margarite pseudomorphs after kyanite in Glen Esk, Scotland. Amer. Miner. 66, 196-200.

Beech, E. M. \& Chadwick, B. 1980: The Malene supracrustal gneisses of northwest Buksefjorden: their origin and significance in the Archaean crustal evolution of southern West Greenland. Precambrian Res. 11, 329-356.

Burnham, C. W. 1975: LCLSQ (MIV): A Fortran IV computer program for least-squares refinement of crystallographic lattice parameters. Unpublished manuscript.

Chatterjee, N. D. 1970: Synthesis and upper thermal stability of 2M-margarite, $\mathrm{CaAl}_{2}$ $\left(\mathrm{Al}_{2} \mathrm{Si}_{2} \mathrm{O}_{10}\right) /(\mathrm{OH})_{2}$. Schweiz. Miner. Petrol. Mitt. 54, 753-767.

Deer, W. A., Howie, R. A. \& Zussman, J. 1962: ROCK-FORMING MINERALS, 3. Sheet silicates. 270 pp. New York: Wiley.

Guidotti, C. V. \& Cheney, J. T. 1976: Margarite pseudomorphs after chiastolite in the Rangely area, Maine. Amer. Miner. 61, 431-434.

Guidotti, C. V., Post, J. L. \& Cheney, J. L. 1979: Margarite pseudomorphs after chiastolite in the Georgetown area, California. Amer. Miner. 64, 728-732.

Höck, V. 1974: Coexisting phengite, paragonite and margarite in metasediments of the Mittlere Hohe Tauern, Austria. Contr. Miner. Petrol. 43, 261-273.

Storre, B. \& Nitsch, K. H. 1974: Zur Stabilität von Margarit im System CaO- $\mathrm{Al}_{2} \mathrm{O}_{3}-\mathrm{SiO}_{2}-\mathrm{H}_{2} \mathrm{O}$. Contr. Miner. Petrol. 43, 1-24.

Velde, B. 1971: The stability and natural occurrence of margarite. Mineral. Mag. 38, 317-323.

Department of Geological Sciences, 